\title{
Comparison Effect on Biogas Production from Vegetable and Fruit Waste with Rumen Digesta Through Co-Digestion Process
}

\author{
Anika Tasnim, Muhammad Rashed Al Mamun, Md. Anwar Hossen, Md Towfiqur Rahman and Md. \\ Janibul Alam Soeb
}

\section{ABSTRACT}

Biogas is the best renewable energy as it can be produced from any biomass for example any plant or living organism. The purpose of this research was to produce biomethane from co-digestion of vegetable and fruit waste with rumen digesta through anaerobic digestion process. In this research, two trials of experiment were conducted. Each trial has three different sample with different mixing ratios. Raw materials used in the experiment was rumen digesta of goat and cow, potato, capsicum, cucumbers, onions, radish, cauliflower, carrot, leafy vegetables, apple, banana, and papaya. In each sample, 1200 gram of raw materials were used. Hydraulic retention time was 30 days. Data was collected by water displacement method. The experiment found that the gas production started from 2nd or 3rd days and stops in 28th or 29th day. Highest production of biogas was $35,33,30,40,50$ and $35 \mathrm{~mL} /$ day on the 17 th, 14th, 17th, 11th, 12th and 7 th day at the mixing ratios of $1: 1: 2,1: 2: 1$, 1:1.5:1.5, 1:0.5:0.5, 1:2:2 and 1.5:1.5:1 (Rumen Digesta: Vegetable Waste: Fruit Waste) respectively. The study suggests making digester for the recycling of waste to produce biogas, a renewable and environment friendly energy.

Keywords: Anaerobic co-digestion, biogas, rumen digesta, vegetable and fruit waste.
Published Online: January 24, 2022

ISSN: $2736-5506$

DOI : $10.24018 /$ ejenergy.2022.2.1.38

\section{A. Tasnim}

Department of Farm Power and Machinery, Sylhet Agricultural University, Bangladesh. (e-mail: tasnimanika694@gmail.com)

M. R. A. Mamun*

Department of Farm Power and Machinery, Sylhet Agricultural University, Bangladesh.

(e-mail: rashed.fpm@sau.ac.bd)

M. A. Hossen

Bangladesh Rice Research Institute, Bangladesh.

(e-mail: ahossenbrri@gmail.com)

M. T. Rahman

Department of Farm Power and Machinery,

Sylhet Agricultural University, Bangladesh.

(e-mail: towfiq.fpm@sau.ac.bd)

M. J. A. Soeb

Department of Farm Power and Machinery,

Sylhet Agricultural University, Bangladesh.

(e-mail: janibul.fpm@sau.ac.bd)

*Corresponding Author

\section{INTRODUCTION}

Energy is an indispensable factor for development of human. People, all over the world, cannot even think to do regular house works for example cooking, storage of food, lighting home without the supply of sufficient energy. Currently, fossil fuels are the cardinal source of energy which can supply around $80 \%$ of the world's needed energy. Fossil fuel is fuel, formed by natural method such as anaerobic decomposition of buried dead organism. These microorganisms have a limited age of millions of years and sometimes more than 650 million years [1]. Because of the shortage of fossil fuel, the cost will also increase with time. In addition, the burning of fossil fuels generates carbon dioxide (21.3 billion tons) every year. Carbon dioxide is known as greenhouse gas that expands radiative forcing and contribute to climate change. However, within 1000 years, it will not be possible to reverse the condition of climate which was occurred by the emission of carbon dioxide [2]. An effort of global world to generate renewable energy is the best solution to overcome global warming and the crisis of energy demand [3]. Biomass refers to all unprocessed material which survive in the environment. It can be either plant or animal origin [4]. The sources of biomass are municipal solid waste, sugarcane, bamboo, corn, miscanthus, vegetable waste fruit waste, paper, cow dung, human excreta, rumen digesta. It is practical that the generated energy from biomass has no negative shock on the surroundings. Moreover, the cost of production process will be low in amount and make more profit as energy will be produced from readily and locally available substances. Individuals may select to comprise their food waste to produce a useful fertilizer. In 2010, 150 million tons' food waste produced across world [5]. The amount of total solid in food waste is $18-31 \%$ and water are $70-80 \%$ [6]. Vegetable and fruit waste is a biodegradable material found in large quantities from various sources such as domestic, industries, municipalities, and markets. On the other hand, Rumen digesta defines as undigested animal waste which store into stomach of animal. There are various types of method available to convert waste into biogas. Anaerobic digestion is known as a fruitful left-over thing's treatment method because organic matter in food waste and rumen digesta are suitable for anaerobic microbial growth. Recycling of these wastes to produce biogas provides some energy and can have a significant effect on environment. Furthermore, biogas which is mainly $\mathrm{CH}_{4}$, and $\mathrm{CO}_{2}$ is the only cheap alternative renewable source of energy [7]. A four-stage mechanism is now widely accepted. There are four 
pivotal steps of anaerobic digestion involve hydrolysis, acidogenesis, acetogenesis and methanogenesis in Fig. 1. Organic carbon is mainly converted into carbon dioxide and methane in these steps [8]. Chemical reaction can narrate the complete process where organic material is biochemically converted into their monomers, such as, glucose into carbon dioxide $\left(\mathrm{CO}_{2}\right)$ and methane $\left(\mathrm{CH}_{4}\right)$ by the anaerobic microorganisms.

$$
\mathrm{C}_{6} \mathrm{H}_{12} \mathrm{O}_{6} \rightarrow 3 \mathrm{CO}_{2}+3 \mathrm{CH}_{4}
$$

The process is shown below by diagram:

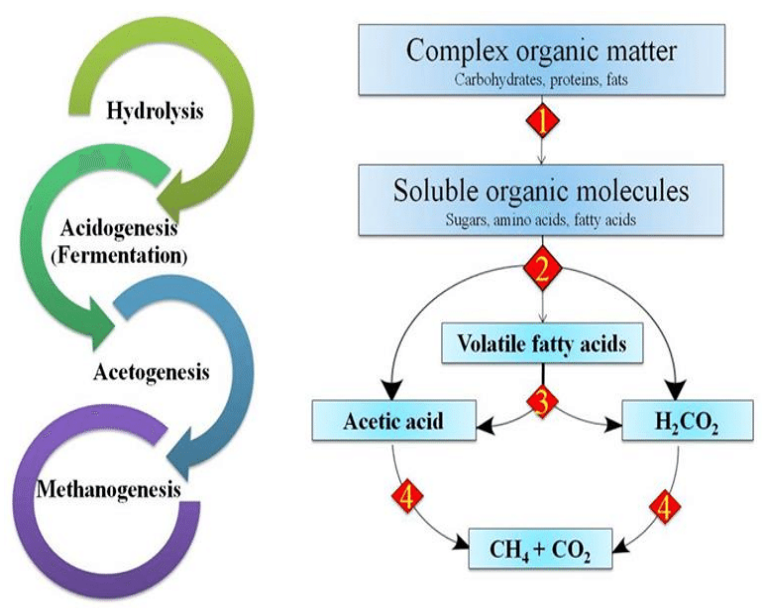

Fig. 1. Anaerobic digestion mechanism.

Numerous studies are conducted on the generation of biogas from cow dung, solid waste, fruit waste. But there are few reports are available on rumen digesta fermentation. Digestion of cow waste: fruit waste, cow waste: vegetable waste and vegetable waste: fruit waste in the ratio of $0.50: 0.50,0.75: 0.25,0.50: 0.50$ respectively produced the highest cumulative biogas 836,811 and $756 \mathrm{~mL} / \mathrm{g}$ VS [9]. An experiment was investigated to grasp the potentiality of biogas production from slaughterhouse waste and located that the ratio of $75 \%$ slaughterhouse waste and $25 \%$ cow dung is the best for biogas production [10]. There is no need to add nutrient or chemicals to generate biogas when fruit waste, vegetable waste and cow manure are blended [11].
The motive of this experiment is to grasp the comparison effect of mixture of waste (rumen digesta, fruit and vegetable waste) for biogas production. Six different ratios of sample were examined to know the optimum mixing ratios for production of biogas. Also, this paper focus on to control environmental pollution by recycling these waste.

\section{MATERIALS AND METHODS}

Suitable method, fermented materials and design for collecting valid data is chosen through careful analysis.

\section{A. Collection of Raw Materials}

Three digestible waste materials (e.g. Rumen digesta, vegetable and fruit waste) were collected from different places. Rotted vegetables and fruits waste were collected from market and other houses. The vegetable waste consisted of potato, capsicum, cucumbers, onions, radish, cauliflower, carrot and leaf vegetables. Fruit wastes were apple, banana, papaya. Rumen digesta (cow and goat rumen waste) was gathered from different slaughterhouses. Cow rumen and goat rumen digesta were collected from slaughterhouse.

\section{B.Preparation of Sample}

Two trials of the experiments were studied to know the comparison effect of different mixing ratios of rumen digesta: vegetable waste: fruit waste. Total nine types of samples were made and designated as R1, R2, R3, R4, R5 and R6. To prepare sample, at first, weight of raw materials was taken. Rumen digesta, vegetable and fruit waste was mixed with a stirring rod at different mixing ratios to get the contact of each waste to achieve homogenous condition. The ratio of rumen digesta, vegetable and fruit waste and quantity of raw materials (gram) used in reactors are shown in table-I. Blended materials were mingled with water at the ratio of $1: 1$ $(w / w)$. Blood from slaughterhouse was mixed with sample as blood contain active bacteria. $\mathrm{pH}$ of slurry before and after retention time and temperature was recorded during experiment time as shown in Table II. Anaerobic digestion procedure was conducted with laboratory scale batch digesters of $3000 \mathrm{~mL}$ working volume. $80 \%$ of digester that means $2400 \mathrm{~mL}$ was filled with prepared material.

TABLE I: WEIGHT OF PREPARED SAMPLE FOR CO-DIGESTION

\begin{tabular}{rcccccc}
\hline \hline Beaker & Ratio & Rumen Digesta $(\mathrm{g})$ & Vegetable Waste $(\mathrm{g})$ & Fruit Waste $(\mathrm{g})$ & Water $(\mathrm{mL})$ & Total Weight $(\mathrm{g})$ \\
\hline \hline $\mathrm{R}_{1}$ & $1: 1: 2$ & 300 & 300 & 600 & 1200 & 2400 \\
$\mathrm{R}_{2}$ & $1: 2: 1$ & 300 & 600 & 300 & 1200 & 2400 \\
$\mathrm{R}_{3}$ & $1: 1.5: 1.5$ & 300 & 450 & 450 & 1200 & 2400 \\
$\mathrm{R}_{4}$ & $1: 0.5: 0.5$ & 600 & 300 & 300 & 1200 & 2400 \\
$\mathrm{R}_{5}$ & $1: 2: 2$ & 240 & 480 & 480 & 1200 & 2400 \\
$\mathrm{R}_{6}$ & $1.5: 1.5: 1$ & 450 & 450 & 300 & 1200 & 2400 \\
\hline \hline
\end{tabular}

TABLE II: PH AND TEMPERATURE OF PREPARED SAMPLE

\begin{tabular}{cccccc}
\hline \hline Reactor & $\mathrm{p}^{\mathrm{H}}$ Before & $\mathrm{p}^{\mathrm{H}}$ After & Change during Digestion & Temperature $\left({ }^{\circ} \mathrm{C}\right)$ & Biogas Production $(\mathrm{mL})$ \\
\hline \hline $\mathrm{R}_{1}$ & 6.5 & 6.6 & 0.1 & 28 & 502 \\
$\mathrm{R}_{2}$ & 5.8 & 6.0 & 0.2 & 27.5 & 447 \\
$\mathrm{R}_{3}$ & 6.4 & 6.5 & 0.1 & 27.5 & 441 \\
$\mathrm{R}_{4}$ & 6.7 & 7 & 0.3 & 28 & 523 \\
$\mathrm{R}_{5}$ & 6.8 & 7.8 & 1 & 28.5 & 791 \\
$\mathrm{R}_{6}$ & 6.2 & 6.5 & 0.3 & 26.8 & 409 \\
\hline \hline
\end{tabular}




\section{Experimental Setup}

Laboratory based batch type experimental arrangement was set by using capacity of $3000 \mathrm{ml}$ three flask digester, one $1500 \mathrm{~mL}$ water-cum-gas chamber flask along with one $1500 \mathrm{ml}$ water collector flask for every supervision. $12 \mathrm{~mm}$ diameter plastic hose pipe used to connect flask digester with water-cum-gas chamber. Tube was operated to allow generated product to pass from digester to water-cum-gas chamber. Furthermore, tube of $10 \mathrm{~mm}$ diameter was applied to connect the water-cum-gas chamber with the water collector flask. These two flasks was connected so that same proportion of water can be transferred into water collector when generated bioenergy started to develop pressure on the water-cum-gas chamber. The amount of water replaced from the flask was equal to the amount of bioenergy produced. The water collector flask was set at an appropriate height to provide a desirable pressure to the gas outlet by water displacement. The gas collected pipe was connected together with tube made by glass and opposite side of the pipe linked with water and gas collected flask. Displaced water collected flask was joined by inserting hose pipe on the upper portion of the gas and water collected chamber. A valve was used to control gas flow from the digester. The experimental set up is shown a schematic diagram in Fig. 2.

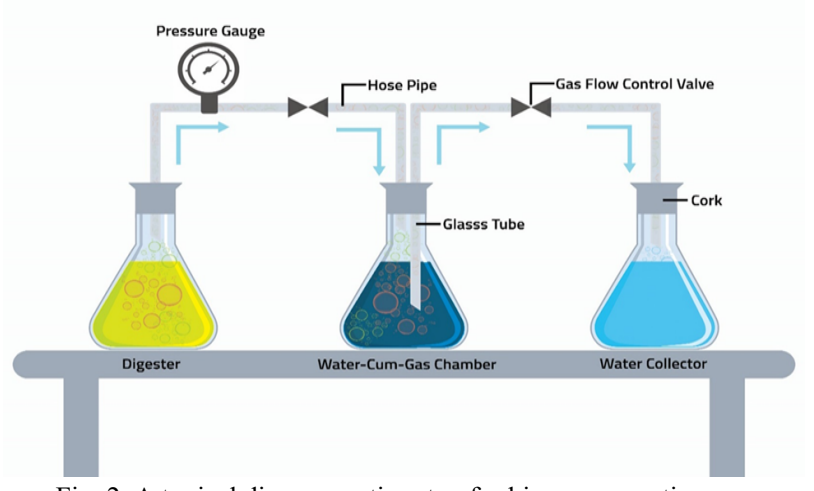

Fig. 2. A typical diagrammatic setup for biogas generation .

\section{Observation}

Six supervisions were done within two trial. Each trial comprised of three different observations. Investigation started immediately after finishing the filling of digester with different mixing ratios of raw materials. The digesters were left for 30 days so that the organic load could degraded by micro-organism. Gas was started to produce from first operating day, and it was almost finished at 27/28th digestion day. Temperature was recorded daily. The temperature was varied from $25^{\circ} \mathrm{C}$ to $35^{\circ} \mathrm{C}$ during the study period.

\section{E. Measurement of Biogas}

The biogas generated from each of the sample in the 3000 $\mathrm{mL}$ flask was estimated by water displacement method. As the biogas generates continuously, water is displaced into the water collector flask due to the pressure of produced biogas. This procedure is known as water-displacement technique. During the measurement of production, the control on the digester was released so that produced gas could flow into water collector. Experimented data was gathered in the same time (12 pm) every day from the selected experimental lab.

\section{F. Analytical Method}

pH meter which is originated by HANNA Instruments, Inc. Romania (HI98107) was used to measure $\mathrm{pH}$ of samples. Daily temperature of study period as well as the daily ambient temperature of the environment was measured by Thermometer (TP300, China). Temperature range of TP300 thermometer is $-50^{\circ} \mathrm{C} \sim+300^{\circ} \mathrm{C}$.

\section{RESUlTS}

This experiment was conducted in laboratory and careful observation was done to record data of each trial. Data was recorded by water displacement method.

\section{A. Biogas Production Profile}

The production of biogas from rumen digesta, vegetable waste and fruit waste at mixing ratios of 1:1:2 which is designated as $R_{1}$ is represented in figure 3 . The graph shows that the hydraulic retention period was 30 days and production started from $3^{\text {rd }}$ day as materials began to decompose. The rate gradually increased from $3^{\text {rd }}$ to $12^{\text {th }}$ day. Then it production remains same on next day and again the rate increased from $14^{\text {th }}$ day to $17^{\text {th }}$ day. On $17^{\text {th }}$ day production was in peak point and it was $35 \mathrm{~mL}$. After that generation became slow and started to decrease due to temperature fall. The average gas production was $17 \mathrm{~mL} /$ day.

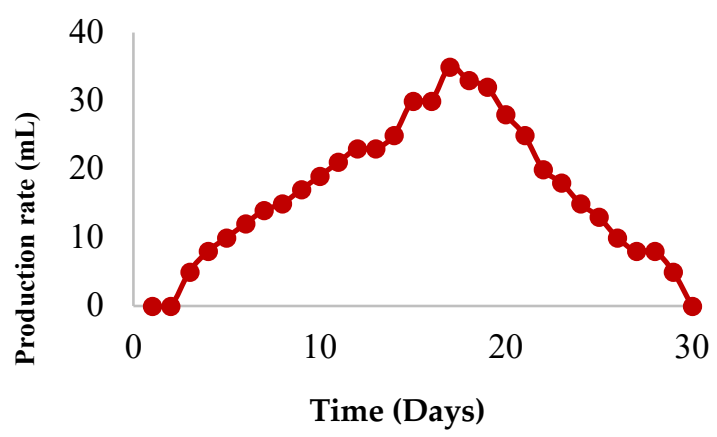

Fig. 3. Biogas production from ratio (1:1:2).

Fig. 4 represents the production rate from raw materials at mixing ratios of 1:2:1 which is denoted by $\mathrm{R}_{2}$. Under 30 retention period, generation began from $3^{\text {rd }}$ day and gradually increased to $15^{\text {th }}$ day. $33 \mathrm{~mL} /$ day was recorded as maximum production of biogas which was produced at $14^{\text {th }}$ and $15^{\text {th }}$ day. After 15th day of digestion period production started to fall due to temperature. From $28^{\text {th }}$ to $30^{\text {th }}$ the generation was nil. The average rate of production was $15 \mathrm{~mL} /$ day.

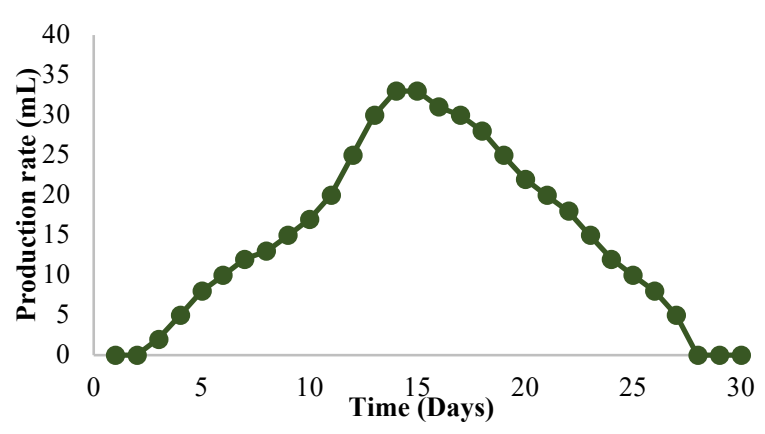

Fig. 4. Biogas production from ratio (1:2:1). 
The biogas yield from rumen digesta, vegetable waste and fruit waste at mixing ratios of 1:1.5:1.5 which is designated as $\mathrm{R}_{3}$ is represented in Fig. 5. Generation started from $3^{\text {rd }}$ day and amount was $1 \mathrm{~mL}$ which is very low. Production started to increase gradually from that day to $16^{\text {th }}$ day.

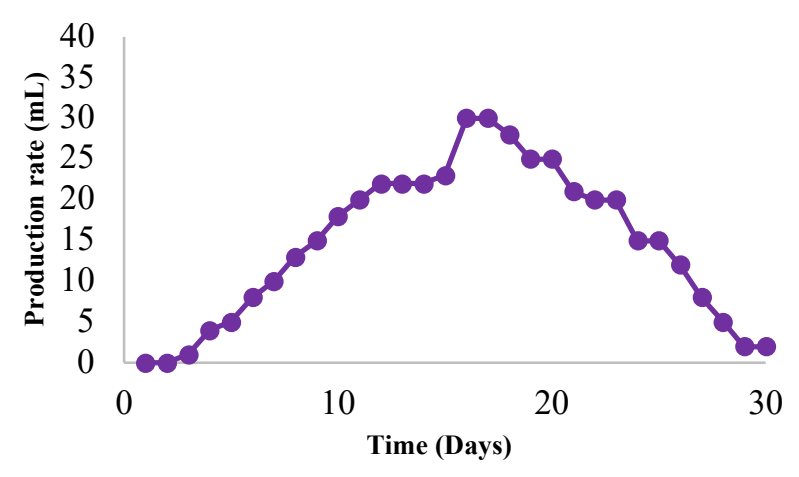

Fig. 5. Biogas production from ratio (1:1.5:1.5).

On the $17^{\text {th }}$ day production remains same. The result of the gas production shows maximum on $16^{\text {th }}$ and $17^{\text {th }}$ day with the gas generation of $30 \mathrm{~mL}$. Then started to decrease from next day due to temperature fall and reached $2 \mathrm{~mL}$ on $29^{\text {th }}$ day. The rate followed same by next day. The average rate of production was $14 \mathrm{~mL} /$ day.

Fig. 6 represents the graph for the production of biogas from rumen digesta, vegetable waste and fruit waste at the mixing ratio of 1:0.5:0.5 which is denoted as $\mathrm{R}_{4}$. In this trial, production starts from the first day and it started to increase gradually due to desired temperature. The highest production was recorded on $11^{\text {th }}$ day and it was $40 \mathrm{~mL}$ which is high compared to previous trial. After $11^{\text {th }}$ day, production rate started to decrease. The lowest data was recorded $5 \mathrm{~mL}$ on $26^{\text {th }}$ and $27^{\text {th }}$ day. After that gas was not produced in this trial.

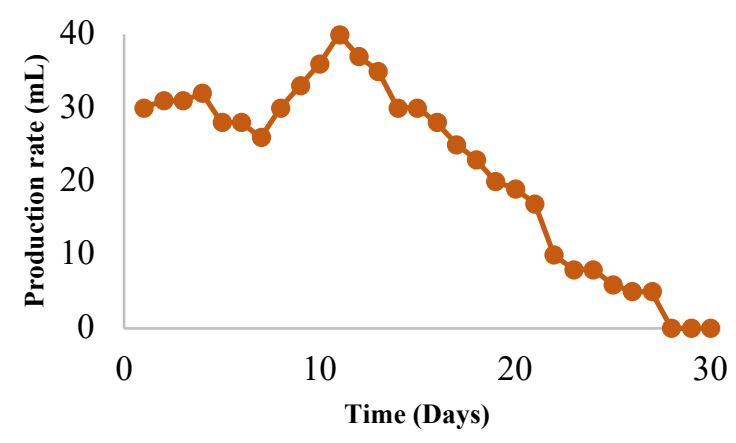

Fig. 6. Biogas production from ratio (1:0.5:0.5).

The generation rate of biogas from rumen digesta, vegetable waste and fruit waste at mixing ratio 1:2:2 which is designated as $R_{5}$ is shown in Fig. 7. The highest data of production was recorded in this ratio. Production started from the second day and it was $5 \mathrm{~mL}$. Generation rate gradually increased till $12^{\text {th }}$ day and maximum production recorded on that day which was $50 \mathrm{~mL}$. After that day production started to decrease gradually due to temperature fall. The lowest data recorded was $2 \mathrm{~mL}$ on $30^{\text {th }}$ day. The average rate of production was $25 \mathrm{~mL} /$ day.

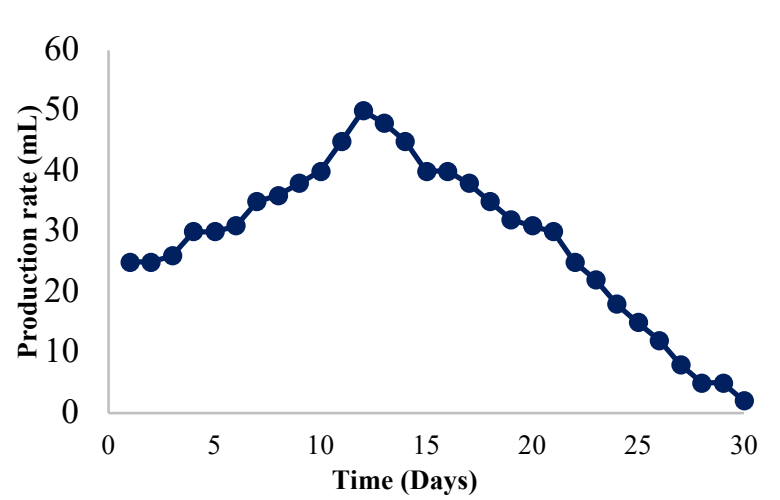

Fig. 7. Biogas production from ratio (1:2:2).

Fig. 8 demonstrates the graph for the production of biogas from rumen digesta, vegetable waste and fruit waste at the mixing ratio of 1.5:1.5:1 which is $\mathrm{R}_{6}$. Generation started from $1^{\text {st }}$ day. The amount was $3 \mathrm{~mL}$ which was so little. Production rate decreased on $2^{\text {nd }}$ and $3^{\text {rd }}$ day rather than increased. The rate gradually raised from $4^{\text {th }}$ day to $7^{\text {th }}$ day and maximum data recorded was on that day which was $35 \mathrm{~mL}$. Generation rate was not so high due to temperature fluctuation and $\mathrm{P}^{\mathrm{H}}$ of sample. The lowest data was $1 \mathrm{~mL}$ which was recorded on $29^{\text {th }}$ day. The average production rate was $14 \mathrm{~mL}$ per day.

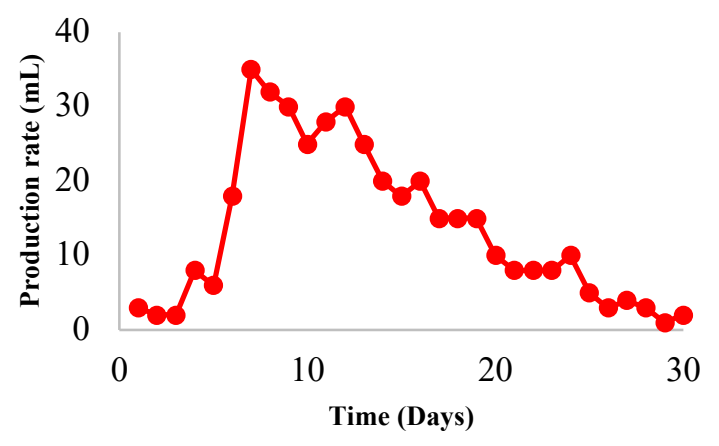

Fig. 8. Biogas production from ratio (1.5:1.5:1).

\section{B. Comparability results of Biogas Generation}

Fig. 9 represents variation in production of gas after every 10 days. The graph also reveals that the production rate of each mixture of first trial was in peak point at $2^{\text {nd }} 10$ days (1120 days) due to the full decomposition of raw material. Among these three mixtures, the highest average rate of 10 days was found $28 \mathrm{~mL}$ from first mixture which is denoted by $R_{1}$ at the ratio of rumen digesta: vegetable waste: fruit waste (1:1:2). The rate of yield was low between 1-10 days compared with $2^{\text {nd }}$ and $3^{\text {rd }} 10$ days.

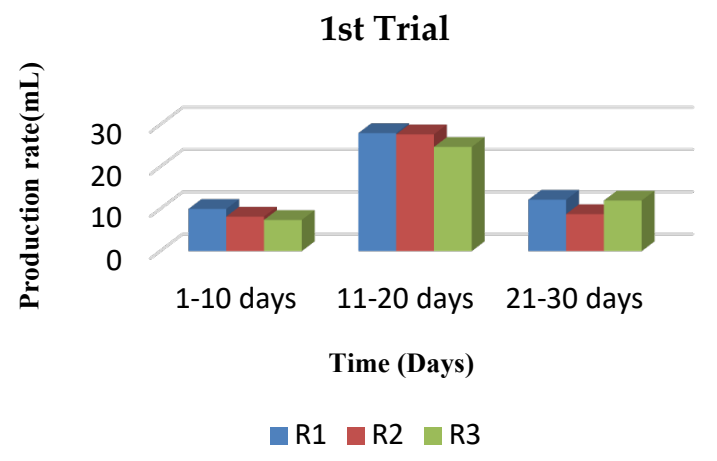

Fig. 9. Observation of gas production at interval of 10 days ( $1^{\text {st }}$ Trial). 
Fig. 10 illustrates variation in production of gas $\left(2^{\text {nd }}\right.$ Trial $)$ after every 10 days. The graph also shows that the generation rate of two mixtures which is denoted by $R_{5}$ and $R_{6}$ was in peak point at $2^{\text {nd }} 10$ days (11-20 days) due to the full decomposition of raw material. Among these three mixtures, the highest average rate of 10 days was found $40.4 \mathrm{~mL}$ from second mixture which is denoted by $\mathrm{R}_{5}$ at the ratio of rumen digesta: vegetable waste: fruit waste $(1: 2: 2)$. The rate of yield was low between 21-30 days compared with other days.

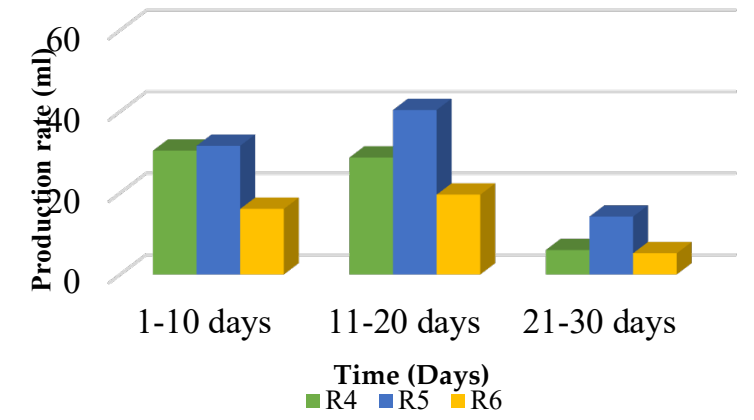

Fig. 10. Observation of gas production at interval of 10 days ( $2^{\text {nd }}$ Trial).

\section{Accumulate Gas Production ( $m L$ )}

Fig. 11 represents the accumulative gas production from different mixing ratios of rumen digesta, vegetable waste and fruit waste. The line graph reveals that cumulative production was $502 \mathrm{~mL}, 447 \mathrm{~mL}, 441 \mathrm{~mL}$ from rumen digesta, vegetable waste and fruit waste respectively. At this trial highest production was found from raw material at the ratio of 1:1:2.

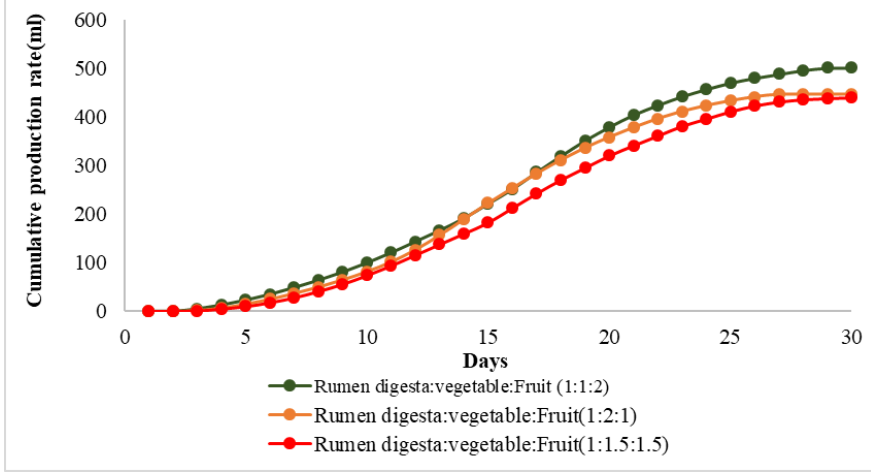

Fig. 11. Cumulative production from $1^{\text {st }}$ trial.

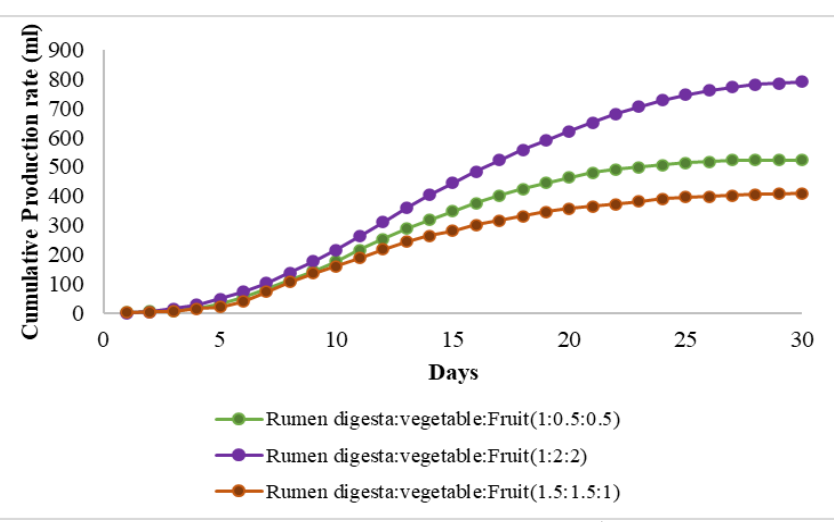

Fig. 12. Cumulative production from $2^{\text {nd }}$ trial.

Fig. 12 demonstrates the accumulative biogas generation from different mixing ratios of rumen digesta, vegetable waste and fruit waste. The figure reveals that cumulative production was $523 \mathrm{~mL}, 791 \mathrm{~mL}, 409 \mathrm{~mL}$ from rumen digesta, vegetable waste and fruit waste respectively. At this trial highest production observed from raw material at the mixing ratio of 1:2:2 which was $791 \mathrm{~mL}$.

\section{Effect of TS, VS and MC on biogas yield}

This research work also observed different concentrations of percentage total solid (\%TS) and percentage volatile solid $(\% \mathrm{VS})$ of different raw materials that were co digested and their effect on amount of biogas production in order to determine suitable value of \%TS and \%VS for optimum biogas production. The appropriate analysis of produced biogas against \% $\% \mathrm{TS}, \% \mathrm{VS}$ and $\% \mathrm{MC}$ is shown in following Table III.

\begin{tabular}{ccccc}
\multicolumn{5}{c}{ TABLE III: APPROPRIATE ANALYSIS OF BIOGAS YIELD WITH } \\
\multicolumn{4}{c}{ TOTAL SOLID, VOLATILE SOLID AND MOISTURE CONTENT } \\
\hline \hline Sample & $\begin{array}{c}\text { \% Total } \\
\text { Solid }\end{array}$ & $\begin{array}{c}\text { \% Volatile } \\
\text { Solid }\end{array}$ & $\begin{array}{c}\text { \% Moisture } \\
\text { Content }\end{array}$ & $\begin{array}{c}\text { Cumulative } \\
\text { Biogas Yield } \\
(\mathrm{mL})\end{array}$ \\
\hline \hline & & & & \\
$\mathrm{R}_{1}$ & 8.9 & 78.4 & 92 & 502 \\
$\mathrm{R}_{2}$ & 8.5 & 67.6 & 85 & 447 \\
$\mathrm{R}_{3}$ & 6.85 & 59.5 & 82.9 & 441 \\
$\mathrm{R}_{4}$ & 10.0 & 90.8 & 88.5 & 650 \\
$\mathrm{R}_{5}$ & 10.3 & 93.5 & 91.5 & 862 \\
$\mathrm{R}_{6}$ & 3.5 & 57.3 & 80 & 409 \\
\hline \hline
\end{tabular}

From this table it is evident that biogas production rate increases with increasing rate of $\% \mathrm{TS}, \% \mathrm{VS}$ and $\%$ moisture content and decreases with the decreasing rate of $\% \mathrm{TS}, \% \mathrm{VS}$ and $\%$ moisture content. Percentage of total solid accumulation would no longer contribute to up warding biofuel generation after a certain period.

\section{E. Temperature Profile}

Fig. 13 represents daily temperature of each trial. Temperature was recorded during anaerobic digestion period. The temperature was in mesophilic range during trial. The highest temperature was $35^{\circ} \mathrm{C}$ and $33^{\circ} \mathrm{C}$ during $1^{\text {st }}$ and $2^{\text {nd }}$ trial respectively. The lowest temperature recorded $27^{\circ} \mathrm{C}$ and $26^{\circ} \mathrm{C}$ from $1^{\text {st }}$ and $2^{\text {nd }}$ trial respectively.

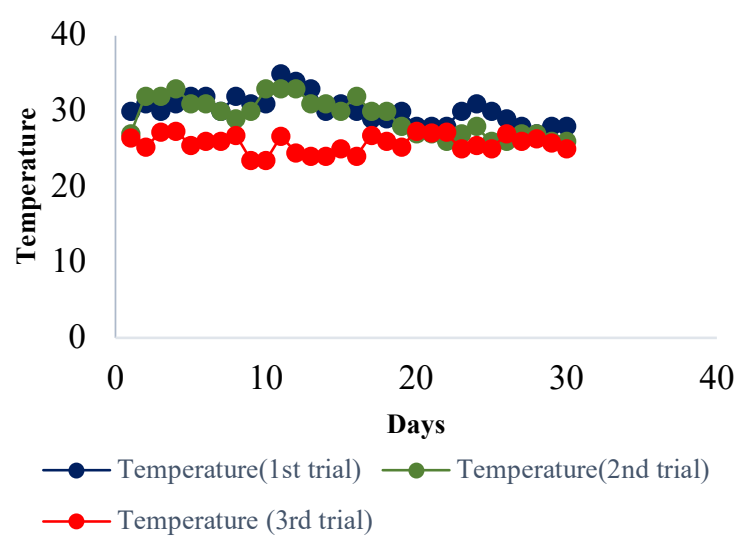

Fig. 13. Daily temperature digestion day

\section{Discussion}

The present study describes the production of biogas at different mixing ratios and about parameters of anaerobic digestion process. The parameters which observed in this 
study are temperature, $\mathrm{pH}, \% \mathrm{TS}, \% \mathrm{VS}, \% \mathrm{MC}$. Temperature is taken as an important factor for the production of biogas. The highest temperature $\left(33^{\circ} \mathrm{C}\right)$ was observed in second trial at the $11^{\text {th }}, 12^{\text {th }}$ and $13^{\text {th }}$ day. Production rate was also high in these days. Although $40^{\circ} \mathrm{C}$ temperature is optimum for maximum gas production, but in some cases, increase in biogas production occurs between the temperatures of $35^{\circ} \mathrm{C}$ and $40^{\circ} \mathrm{C}$ [12]. The Study [13] also shows that biogas production and methane was also increased with the increasing temperature. $\mathrm{pH}$ is a scale used to determine how acidic or basic a water-based solution is. The $\mathrm{pH}$ of mixtures of sample in this study was $6.5,5.8,6.4,6.7,6.8$ and 6.2 for $\mathrm{R}_{1}, \mathrm{R}_{2}, \mathrm{R}_{3}, \mathrm{R}_{4}, \mathrm{R}_{5}$ and $\mathrm{R}_{6}$ respectively. The result showed that the sample which $\mathrm{pH}$ was 6.8 had the maximum biogas yield followed by the other samples. A research observed that the if the $\mathrm{pH}$ value increased from 5.5 to 7.5 when the $\mathrm{CH}_{3} \mathrm{COOH}$ equivalent and COD concentration was reduced $88.1 \%$ and $18.3 \%$ respectively in the hydrolysate result in $58 \% \mathrm{CH}_{4}$ production in this experiment which is very similar comparison with the present study. [14]. In present study the concentration of TS was measured and recorded. According to result found on present study, cumulative biogas production increases with the increasing of \%TS. After optimum \% TS, production level did not raise with the increase of $\% \mathrm{TS}$ rather it started to fall. In this study, highest cumulative biogas yield was recorded at $10.3 \% \mathrm{TS}$. The result is similar with the result of a research [15] which showed that the reactor with $10 \%$ of total solid content yielded higher biogas compared with other reactors which was filled with material contain $5 \%, 15 \%$ and $20 \%$ TS.

\section{CONCLUSION}

Demand of energy and management of myriad biodegradable waste are cardinal problems faced by the world which is caused by the increasing trend of population and lack of proper planning of urbanization. To overcome this energy crisis, the best solution is to produce a renewable energy source. In this study nine different ratios of materials mixed under three trial. The cumulative production of biogas was $502,447,441,523,791$ and $409 \mathrm{~mL}$ at the mixing ratios of $1: 1: 2,1: 2: 1,1: 1.5: 1.5,1: 0.5: 0.5,1: 2: 2$ and $1.5: 1.5: 1$ (RD: VW: FW) respectively. The result of the study shows that the purpose was achieved successfully. The maximum cumulative biogas produced from sample at the mixing ratios of 1:2:2 (RD: VW: FW) and production was $791 \mathrm{~mL}$. The percentage of total solid, volatile solid and moisture content was also measured. The result shows that production rate changes proportionally with these parameters. The results obtained from this study could be used as a basis for designing large scale anaerobic digesters for treatment of rumen digesta, vegetable waste and fruit waste. Thus, successful implementation of this technique can contribute to control environmental pollution and mitigate energy crisis.

\section{ACKNOWLEDGMENT}

The authors would like to pay special regards to Agricultural and Bio-systems Engineering Lab for this experimentation. Finally, Authors would like to thank different stakeholders for letting us through all the difficulties.

\section{FUNDING}

Authors have no financial support or sponsor for the research work.

\section{CONFLICT OF INTEREST}

Authors declare no conflict of interest.

\section{REFERENCES}

[1] Mann P, Gahagan L, Gordon MB. Tectonic setting of the world's giant oil and gas fields. Journal of AAPG Memoir. 2003; 78: 15-105.

[2] Susan S, Gian KP, Reto K, Pierre F. Irreversible climate change due to carbon dioxide emissions. Proceedings of the Academy of Sciences of the United States of America. 2009; 106-(6): 1704-1709.

[3] Mehedintu A, Sterpu M, Soava G. Estimation and forecasts for the share of renewable energy consumption in final energy consumption by 2020 in the European union. Journal of Sustainability 2018; 10, 1515 .

[4] Zhang C, Su H, Tan T. Batch and semi-continuous anaerobic digestion of food waste in a dual solid-liquid system. Journal of Bioresource Technology. 2014; 145: 10-16.

[5] Zhang C, Su H, Baeyens J, Tan T. Reviewing the anaerobic digestion of food waste for biogas production. Journal of Renewable and Sustainable Energy Reviews. 2013; 38: 383-392.

[6] Andersson FAT, Karlsson A, Svensson BH, Ejlertsson J. Occurrence and abatement of volatile sulfur compounds during biogas production. JAPCA J. Air Waste Ma. 2004; 54(7): 855-861.

[7] Angelidaki I, Ellegaard L, Ahring BK. Applications of the anaerobic digestion process. Springer 2003; 1- 33.

[8] Mamun MRA, Torii S. Anaerobic co-digestion of biodegradable biomass for biomethane generation. Journal of the Japan Institute of Energy. 2014; 94: 588-593.

[9] Leta D, Solomon L, Chavan RB, Daniel M, Anbessa D. Production of biogas from fruit and vegetable wastes mixed with different wastes. Environment and Ecology Research. 2015; 3(3): 65-71.

[10] Rouf MA, Islam MS, Rabeya T, Mondal AK, Khanam M, Samadder $\mathrm{PR}$, et al. Biogas from slaughter house waste and optimization of the process. Bangladesh Journal of Scientific and Industrial Research. 2016; 51(3): 203-214.

[11] Uzodinma EOU, Ofoefule AU, Eze JI, Onwuka ND. Optimum mesophilic temperature of biogas production from blends of agrobased wastes. Trends in Applied Sciences Research. 2007; 2: 39-44.

[12] Rameshprabu R, Yuwalee U. Effect of temperature on the performance of biogas production from Duckweed. Chemistry Research Journal. 2016; 1(1): 58-66.

[13] Jeong IkO, Jechan L, Kun-Yi AL, Eilhann EK, Yiu FT. Biogas production from food waste via anaerobic digestion with wood chips. Energy \& Environment. 2018; 0(0): 1-8.

[14] Paramaguru G, Kannan M, Lawrence P Thamilselvan D. Effect of total solids on biogas production through anaerobic digestion of food waste. Desalination and Water Treatment. 2017; 63: 63-68.

[15] Donald L. Biomass for renewable energy, fuels and chemicals. Academic Press. 1998; 445-491.

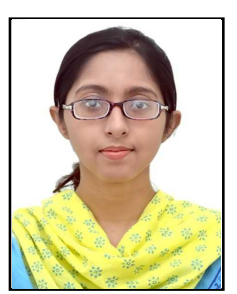

Anika Tasnim completed her B.Sc. in Agricultural Engineering from Sylhet Agricultural University, Sylhet. She received her Master of Science in Farm Power and Machinery from Sylhet Agricultural University, Sylhet. She has research interest on PostHarvest Technology Design, Precision Agriculture, Agricultural Machinery Design and Renewable Energy. 


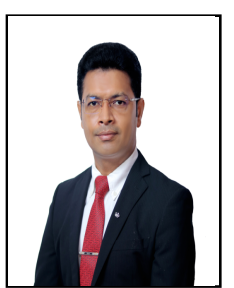

Muhammad Rashed Al Mamun, PhD was born in Kaliganj, Dhaka, Gazipur, Bangladesh. Dr. Al Mamun successfully completed B.Sc. in Agricultural Engineering and MS in Farm Power and Machinery from Bangladesh Agricultural University, Mymensingh, Bangladesh. Dr. Al Mamun is currently a Professor of Farm Power and Machinery, Faculty of Agricultural Engineering and Technology at Sylhet Agricultural University, Bangladesh. Prior to this position, he worked as a Lecturer and Assistant Professor for the same University and Agricultural Engineer at the Department of Agricultural Extension in the Ministry of Agriculture, Dhaka, Bangladesh. He also worked as the VISITING Professor at Kumamoto University, Japan, Shahjalal University of Science and Technology, Forestry Science and Technology School and Agricultural Training Institute in Sylhet, Bangladesh. He received $\mathrm{PhD}$ in Advanced Technology from the Kumamoto University, Japan. Dr. Al Mamun also worked as a Research Scientist in Ground Water Leadership Program for conserving safe ground water in Kumamoto University, Japan. Dr. Al Mamun published many peer-reviewed articles and written 01 book on Renewable Energy. He presented his research achievement in many International and national Scientific Conferences, Symposiums and Workshops. He has achieved Kumamoto University President Award and Best Publication Award, Sylhet Agricultural University. He has also awarded "Kingdom of Saudi Arabia for Environmental Management in the Islamic World". Recently, he has achieved "Venus International Research Award for Outstanding Scientist in Farm Power and Machinery. Presently, Dr. Al Mamun is working simultaneously in different research projects such as agricultural mechanization, tea processing technology, development of an efficient codigestion mixing ratio for biogas production using biodegradable material with rumen digesta, development of economic biogas purification technologies and solid waste management challenges in Sylhet City Corporation. His research interests include renewable energy, agricultural machinery, precision agriculture, remote sensing, groundwater hydrology, wastes management and GIS based agricultural policy management for sustainable agriculture in rural areas. Dr. Al Mamun is a member of Engineering Institute of Bangladesh (IEB), Krishibid Institute of Bangladesh (KIB) and Asia-Pacific Chemical, Biological \& Environmental Engineering Society (APCBEES). Dr. Al Mamun has been selected as a advisory board member, editorial board member and reviewer of the many national and International journals.

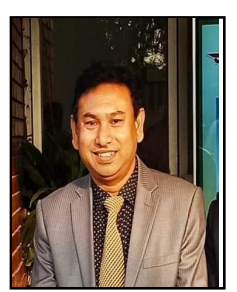

Anwar Hossen is working as a Senior Scientific Officer in the FMPHT Division of BRRI. He made a contribution to farm machinery, postharvest processing, storage, and drying technology design and development suitable for Bangladesh's condition. Currently, he is working on conservation agriculture, rice transplanting (both manual and power operated), weeding, and deep placement of fertilizer technology design and development especially mechatronics and digitalization of the machinery.

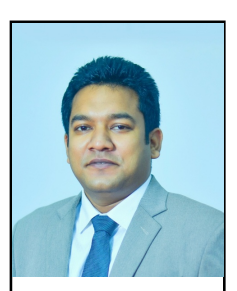

Towfiqur Rahman currently working as an assistant professor at the Department of Farm Power and Machinery, Faculty of Agricultural Engineering and Technology, Sylhet Agricultural University, Bangladesh. He received his M. Sc. in Farm Power and Machinery from Bangladesh Agricultural University, Mymensingh. Currently he is doing $\mathrm{PhD}$ in UNIVERSITY of NEBRASKA-LINCOLN, USA. He loves to work with Computer vision system, Remote sensing, Machine learning, Precision Agriculture, Agricultural Machinery Design.

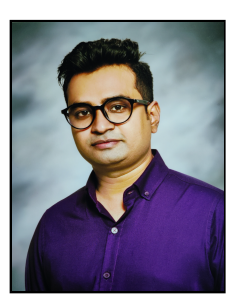

Janibul Alam Soeb, currently working as an assistant professor at the Department of Farm Power and Machinery, Faculty of Agricultural Engineering and Technology, Sylhet Agricultural University, Bangladesh. He received his M. Sc. in Optics and Photonics from Karlsruhe Institute of Technology, Germany and Aix Marseille University, France. He did his B. Sc. in Electrical and Electronic Engineering from University of Dhaka, Bangladesh. He loves to work with renewable energy, non-linear optics, attosecond science and laser technology. 